\title{
Ideological and Political Education in Colleges and Universities in the New Media Era _-Innovation research based on sociological perspective
}

\author{
Jiaxu Wu \\ School of Politics and Administration, School of Wuhan University of Technology, Wuhan 430000, \\ China \\ 280028328@qq.com
}

Keywords: New Media, Ideological and political education in Universities, Subject consciousness, Social Anomie, Campus subculture.

\begin{abstract}
The new wave of science and technology revolution, which emerged in the second half of the 20th century, pushes mankind to a new era - new media era. The new media era is a brand-new information age. The new features of the times appeared in the new media era has a profound influence on ideological and political education in colleges and universities, which not only puts forward new demands for ideological and political education, but also creates new opportunities for ideological and political education in colleges and universities. From the sociological perspective, this article carries out innovative research of ideological and political education in colleges and universities in the new media era, and puts forward reasonable development strategy.
\end{abstract}

\section{Introduction}

The new wave of science and technology revolution, which emerged in the second half of the 20th century, pushes mankind to a new era - new media era. The new media era is a brand-new information age. The new features of the times appeared in the new media era has a profound influence on ideological and political education in colleges and universities, which not only puts forward new demands for ideological and political education, but also creates new opportunities for ideological and political education in colleges and universities.

\section{The present situation of ideological and political education in colleges and universities in the new media era}

The new media refers to "the media form based on internet technology, digital technology and mobile communication technology to provide information and related services for terminals to users, such as computer and mobile phone"1, micro blog, We chat, QQ and so on as its typical manifestation.

According to the new media technology conducted by Wuhan University Youth Media (group), the survey results show that the proportion of college students with mobile phones is $85.8 \%$, while the computer and MPX products are followed by $75.6 \%$ and $51.3 \%$. According to the relevant survey, university students access information from the new media by $62 \%$, the proportions of university students using the Internet to search information, understanding of news and completion of the work are $93.1 \%, 89.1 \%$ and $46.2 \%$ respectively, $66.5 \%$ of college students think that the new media technology has a positive impact on learning.

From the above data, it can be seen that contemporary college students are increasingly dependent on the new media, but the development of Ideological and political education in Colleges and universities is still biased towards the traditional form, and has not yet achieved a comprehensive docking with the new media era. 


\section{The characteristics of college ideological and political education in the new media era}

\subsection{The environment of Ideological and political education in Colleges and universities is becoming more and more complicated}

Under the new media era, society has the characteristics of broking space-time limitation and the dissolution of subject's boundary, resulting in a close network of interactive distance, at the same time, also to a certain extent, decrease of interpersonal communication ability in real life, easy to cause psychological trust crisis and personality disorder and other psychological problems of college students. At the same time, the new media not only provides a good platform for college students to entertain, express speech and interpersonal communication, but also provides a "hotbed" for the breeding of morbid personality and cyber crime. With the deepening of the new media era, the social environment becomes more complicated, the forced inculcation of ideological and political education in colleges and universities and the restricting force of social public opinion have lost their original advantages, and the guidance and standardization work of ideological and political education in colleges and universities has become increasingly difficult to carry out.

\subsection{The subjective characteristics of ideological and political education in colleges and universities are explicit}

In the new media era, the subjective characteristics of ideological and political education in colleges and universities is becoming more and more obvious, mainly including two aspects: one is the subjectivity of educators. The wide application of new media makes the work of ideological and political education in colleges and universities become more flexible. The ideological and political educators in colleges and universities want to get better education effect, one must give full play to his own initiative and enthusiasm, and try to explore new ways and methods to carry out ideological and political education in universities under the new media environment, so that ideological and political education can really penetrate into the heart of college students. The second aspect is the subjectivity of the educated. The characteristics of openness and sharing of new media lead to the massive nature of information resources, which gives college students the opportunity to choose their own information. But in the new media era, the ideological and political education in colleges and universities demands the equal status of the two sides, which will greatly reduce the rejection and alert mentality of the educated, and make the educators more acceptable to guide the substitution of persuasion.

\subsection{Pluralism of information sources of ideological and political education in colleges and universities}

In the traditional form, the information of ideological and political education in colleges and universities is basically derived from the theories, principles and policies in books, with strong political nature, limited information and lack of sense of the times and attraction. In the new media era, the open information dissemination form makes the space-time boundary break through, realizes the information immediacy, makes the university ideological and political education's information source and the dissemination channel become multiplex, three-dimensional, realizes complementary advantages of university ideological and political education and other media. Large or small information resources across the country, all over the world, presented in the diversified form of acceptable image, audio and video, all-round influence university students ' world view, outlook on life and values. Therefore, under the background of the new media era, the information form of ideological and political education in colleges and universities will move from static to dynamic, from plane to stereoscopic, from single to pluralism, and the effect of education is greatly improved.

\subsection{Diversified means of Ideological and political education in colleges and universities}

The arrival of the new media era breaks the space-time limitation of ideological and political education in colleges and universities, which allows educators and educators to spread and acquire knowledge at any place where there is a terminal. Educators can effectively improve the speed and 
efficiency of ideological and political education in colleges and universities by organizing educational videos, open online discussions, writing learning experiences, and so on, which can reduce the burden of educators ' work and make them receptive to the diverse ways of education. To make the ideological and political education in colleges and universities become more vivid and interesting, and the effect can be improved remarkably.

\section{The necessity of ideological and political education in colleges and universities in the new media era}

\subsection{Negative influence of social anomie on college students}

At present, our country is in the period of social transformation, social problems emerge endlessly. For this period of chaos, with the concept of sociologist Durkheim, that is, this society is in an "anomie" state. In his book Suicide Theory, Durkheim describes "anomie" as "a chaotic state in which social norms and social values are relatively fragile, both in the individual and in society". In this chaotic state, the social control and influence of the individual is weakening, and the "Anomie" is also produced. American sociologist Robert Kim Morton's theory of social Anomie also believes that "people's deviant behavior has a profound social structure roots, the disorder of social structure is one of the important causes of social violence."

At present, China is undergoing the "anomie" of social transformation. Colleges and universities as a subsystem of the social system, the two cannot be separated, which means that the social bad style cross the walls of the campus, make the college students inevitably affected by the subtle influence of the whole social environment. Therefore, only by keeping up with the trend of the times, to construct idea and method of ideological and political education for college students, educate college students the ideological and political education, so the students can be free from the erosion of the social bad style, can set up the correct values and ethics, play a positive role for the development of the society.

\subsection{The negative influence of campus subculture on College Students}

What schools teach is often the social mainstream culture; the process of imparting is mainly in the traditional form, not the students' will. Illich mentioned in his book DE schooling Society, "school arbitrarily determines what students learn and what to learn, when students feel more current than the expected to be manipulated, often will strengthen the resistance of the school education". In order to find support for their resistance, the student can find the culture reflect their intention and values, it forms the campus subculture in contrast to campus mainstream culture, and under this guidance, form the informal groups. For the informal groups in the campus, through the conformity theory, will further expanding its influence, and have impact to the campus mainstream culture, this is very bad for college students to establish correct thoughts and values. Therefore, colleges and universities in the new media as the carrier, to build a new mode of conduct ideological and political education, through the way of students are happy to transfer the correct ideological values, ensure that the mainstream culture always stick to the campus "culture highland".

\subsection{Adhere to the network culture position, ensure the ideology is correct, and conform to the trend of the Times}

In the context of the new media era, the cultural exchanges between countries are becoming more and more frequent, which makes the Internet an important place for ideological struggle. Madeleine Albright, the former US secretary of state, made no secret about China when he talked about China, "China will not refuse network, refuse network is refuse modernization, China does not refuse, we have a weapon". Therefore, our country proposes to strengthen and improve the construction of Internet content, promote the orderly operation of network specification, as well as to accelerate the process of education information, constantly improve the attraction and appeal of the moral education work, enhance the pertinence and efficiency of the moral education work. Ideology is the essential attribute of education of ideological politics, and it is the foundation of national stability 
and unity. It is necessary to hold the network culture position and make sure the ideology is correct.

\section{The Strategy of university Ideological and political education in new media era}

\subsection{Actively step in and build a new media platform for university ideological and political education media}

Environment is one of the elements that constitute the education process of ideology and politics. New media environment as a kind of virtual environment, together with social environment, constitute the external environment of the ideological and political education, the new properties and new features that it has also asked the ideological and political education should have new ideas and new thinking, give full play to the talent advantage, technological advantage, audience advantage in colleges and universities, full use of new media technology, build atmosphere of political and ideological education in colleges and universities under the new media environment, strengthen the pertinence, effectiveness and attractiveness of ideological and political education and.

Involved in new media, to build a new platform for the ideological and political education, we should pay attention to the following three aspects: one is to pay attention to use new media information real-time interactive function, strengthen information sharing between educators and the educated with communication, information interaction of benign relationship; Second, we should pay attention to the use of modern education technology, such as pictures, video, audio, etc., to enrich the form, create atmosphere, and enhance the appeal and attraction. Third, we will focus on cultivating a number of online boutique projects with deep cultural connotations, big education significance and wide audiences, and create a group of attractive, influential and demonstrative online brands.

\subsection{Reasonable rectification, update the new media work contents of Ideological and political education}

"The ideological and political education in the new media environment is not the 'digital version' of ideological and political education in the real world." Compared with the official "public opinion field", the online "recessive public opinion field" is more attractive to college students. The ideological and political education under the new media era, therefore, must have a new starting point, to strengthen the building of new media content of work platform, to ensure that the information conforms to the audience wants, needs and desires. Only seize the audience's concerns, can make the ideological and political education really attractive and appealing and targeted.

To reconstruct the content of Ideological and political education under the new media era, mainly from the following two aspects: one is to carry out network transformation of Ideological and political education of universities, combined with the characteristics of new media, the information presented in the form of conform to the network; Secondly, it is important to make a targeted response to Internet hot topics, strengthen the collection and analysis of online public opinion information, and guide students' rational understanding and view of Internet hot topics.

\subsection{Cultivate the subjectivity and innovate the new media work mode of Ideological and political education}

Under the new media era, university students obtain information from the format of "passive accept" to the dynamic type "search" actively, subjective initiative and enthusiasm was released, the dominant position of ideological and political education in colleges and universities continuously emerging, plays more independent and active role. Under this transformation, the ideological and political education should begin from the dominance of "teacher oriented" to "accelerate each other between teaching and studying", from "knowledge inculcation " to "ability cultivation", highlight the subject status of the educates, strive to cultivate educates' subject consciousness, pay attention to improving the capacity of the body of the educates, practical and will be a focus in the ideological and political education from knowledge to ability cultivation. 


\subsection{Focus on specialization and perfect the new media work structure of Ideological and political education}

New media is a comprehensive system integrating multiple knowledge and technology. It is highly specialized and requires professional talents to support it. Therefore, colleges and universities must establish specialized construction idea, increase investment, integration of high quality resources, the network ideological and political education into the work system, cultivating specialized technical talented person, the overall system planning of professional construction and promote the network of ideological and political education, become a solid backing for ideological and political education work of college students under the new media environment.

\section{Conclusions}

The new media era is a new information age. In the face of the new features appearing in Ideological and Political Education under the new media era, promote the integration of the ideological, political education and new media, enhance the effectiveness of the ideological and political education, it is not only the era have entrusted to the new mission of ideological and political education workers, as well as new opportunities for the theory of innovation and development of ideological and political education. Ideological and political education workers should go deep analysis of the new media's influence on ideological and political education in colleges and universities, give full play to the advantages of new media, promote the combination of new media and ideological, political education, with mutual promotion and common development.

\section{References}

[1] Ji Haiju,On the New Opportunities and Challenges of Ideological and Political Education in Colleges and Universities in the New Media Era,Social Sciences in Nanjing,2015,(05):151-157.

[2] Zhu Jiansong,Innovation of Ideological and Political Education in the New Media Environment,Journal of Southwest Jiaotong University(Social Sciences),2014,15(05):89-92.

[3] Qin Hongyi,Xie Siwei,Analysis of Status Quo and Strategy of Ideological and Political Education in Universities Under the Influence of New Media,Journal of Hunan University of Technology(Social Sciences),2017,(03):1-5(2017-09-04).

[4] Wang Limei,On the Innovation of Ideological and Political Education of Colleges and Universities in the New Media,2016. 